\title{
Obtaining new cultures of microorganisms that produces cellulases and xylanases from the sugarcane bagasse
}

\author{
Ludmylla Noleto*, Daniella Moreira, Fabrícia Faria \\ From 5th Congress of the Brazilian Biotechnology Society (SBBIOTEC) \\ Florianópolis, Brazil. 10-14 November 2013
}

\section{Background}

The international energetic system strongly depends on fossil fuels, which causes negative effects in the environment, such as the global warming. Biofuels appear as an environmental and economic alternative for the energetic industry because of their potential source of renewable energy. Several studies are based on sugarcane culture and its derivatives, as bagasse, the sugarcane residue. Bioethanol can be produced by the fermentation of sugar or by the hydrolysis of cellulosic biomass [1]. The plant cell wall is constituted of cellulose (40-50\%), hemicellulose (15-30\%) and lignin (10$30 \%$ ), forming the vegetal biomass. Cellulases are enzymes that form a complex that hydrolyses cellulosic materials, releasing sugars [2]. The main component of hemicellulose is the xylan, which is hydrolyzed by xylanases [3]. Cellulases as xylanases have a great biotechnological potential, they can be used in a variety of field: food, animal feed, textile and paper recycling industries. The sugarcane bagasse (SCB) is the most studied lignocellulosic waste for bioethanol production, because it is a by-product of conventional ethanol and can be find in large amount in Brazil [4]. Nowadays, the process of bioconversion of biomass has high cost and low specific activity of the enzymes that are necessary for the cellulose saccharification [5]. The aim of this research is to obtain microorganisms that hydrolyze the sugarcane bagasse and to quantify the sugar production.

\section{Methods}

The microorganisms present in the $\mathrm{SCB}$ were isolated from three preparations: fresh SCB, SCB buried in soil for about 45 days and humid SCB - collected from two cane fields and stored in refrigerator. To obtain microorganisms, saline solution $(\mathrm{NaCl} 0,15 \mathrm{M})$ and rich medium $(5 \mathrm{~g} / \mathrm{L}$ peptone, $5 \mathrm{~g} / \mathrm{L} \mathrm{NaCl}$ and $10 \mathrm{~g} / \mathrm{L}$ of SCB, $\mathrm{pH}$ 5.0 to 6.0 ) were used, followed by serial dilution. The selection medium contained cellulose and xylan and the enzymatic activity was visualized as a halo of hydrolysis around the culture, using congo red $1 \%$. Submerged fermentation in minimum medium (MM) was used to induce cellulases and xylanases. The determination of enzymatic activity was measured by dinitrosalicilic acid (DNS), using the supernatants of culture as enzymes and Xylan birchwood-Sigma ${ }^{\circledR}, \mathrm{CMC}$-Sigma ${ }^{\circledR}$, AvicelSigma ${ }^{\circledR}$ and Whatman paper filter as substrate for each enzymatic dosage.

\section{Results and conclusions}

Seven cultures were selected (A3, B3, M2, M3, X7, F4 and D2) according to the halo of hydrolysis diameter to determine the enzymatic activity. The culture A3 proved to be a good producer of xylanase. The culture M3 produced cellulases with FPase and CMCase activity, showing that is good for cellulose hydrolysis. The culture X7 simultaneously produces cellulases and xylanases, which favors the hydrolysis of cellulose and hemicellulose using SCB as substrate. Although the activity of avicelase has no results, we cannot conclude that the enzyme was not produced; the microorganisms need to be induced by different specifications.

\section{Acknowledgements}

We thank our professor Fabricia Paula de Faria, who led us in this research, professor Américo José dos Santos Reis from School of Agronomy and Food Engineering, who gave the sugarcane bagasse, and CNPq, which invested in this project.

Published: 1 October 2014 


\section{References}

1. Ogeda TL, Petri DFS: Hidrólise Enzimática de Biomassa. Quím Nova 2010, 33(7):1549-1558

2. Bayer EA, Lamed R: The cellulose paradox: pollutant par excellence and/ or a reclaimable natural resource? Biodegradation 1992, 3(2-3):171-188.

3. Sales MR, Moura RB, Macedo GR, Porto ALF: Variáveis que influenciam a produção de celulases e xilanase por espécies de Aspergillus. Pesquisa Agropecuária Brasileira 2010, 45(11):1290-1296.

4. Melo GR: Produção de celulas e xilanases pelo fungo termofílio Humicola grisea var. thermoidea em diferentes substratos lignocelulósicos. Dissertação (Mestrado), Instituto de Ciencias Biologicas, Universidade Federal de Goiás, Goiânia 2010.

5. Mayrink MICB: Produção de Enzimas Fúngicas e Avaliação do Potencial das Celulases na Sacarificação da Celulose. Dissertação (Mestrado), Universidade Federal de Viçosa, Viçosa, MG 2010.

doi:10.1186/1753-6561-8-S4-P102

Cite this article as: Noleto et al:: Obtaining new cultures of microorganisms that produces cellulases and xylanases from the sugarcane bagasse. BMC Proceedings 2014 8(Suppl 4):P102.

\section{Submit your next manuscript to BioMed Central} and take full advantage of:

- Convenient online submission

- Thorough peer review

- No space constraints or color figure charges

- Immediate publication on acceptance

- Inclusion in PubMed, CAS, Scopus and Google Scholar

- Research which is freely available for redistribution

Submit your manuscript at www.biomedcentral.com/submit 